\title{
Reconstruction High School Student's Conception about Parallel Electrical Circuit Concept Using Virtual Conceptual Change Laboratory (VCCLab)
}

\author{
Yunina Surtiana ${ }^{1, *}$, Andi Suhandi ${ }^{2}$, KL Putri $^{3}$, Wawan Setiawan ${ }^{4}$, Parsaoran Siahaan ${ }^{2}$, \\ Achmad Samsudin ${ }^{2}$, Bayram Costu $^{5}$ \\ ${ }^{1}$ Doctoral Program in Natural Sciences, Universitas Pendidikan Indonesia, Bandung, Indonesia \\ ${ }^{2}$ Department of Physics Education, Universitas Pendidikan Indonesia, Bandung, Indonesia \\ ${ }^{3}$ Master Degree in Physics Education, Universitas Pendidikan Indonesia, Bandung, Indonesia \\ ${ }^{4}$ Computer Science Education Program, Universitas Pendidikan Indonesia, Bandung, Indonesia \\ ${ }^{5}$ Science Education Program, Yildiz Technical University, Turkey
}

Received October 15, 2020; Revised November 26, 2020; Accepted December 20, 2020

\section{Cite This Paper in the following Citation Styles}

(a): [1] Yunina Surtiana, Andi Suhandi, KL Putri, Wawan Setiawan, Parsaoran Siahaan, Achmad Samsudin, Bayram Costu, "Reconstruction High School Student's Conception about Parallel Electrical Circuit Concept Using Virtual Conceptual Change Laboratory (VCCLab), "Universal Journal of Educational Research, Vol. 8, No. 12B, pp. 8169-8177, 2020. DOI: 10.13189/ujer.2020.082620.

(b): Yunina Surtiana, Andi Suhandi, KL Putri, Wawan Setiawan, Parsaoran Siahaan, Achmad Samsudin, Bayram Costu (2020). Reconstruction High School Student's Conception about Parallel Electrical Circuit Concept Using Virtual Conceptual Change Laboratory (VCCLab). Universal Journal of Educational Research, 8(12B), 8169-8177. DOI: 10.13189/ujer.2020.082620.

Copyright $\mathrm{C} 2020$ by authors, all rights reserved. Authors agree that this article remains permanently open access under the terms of the Creative Commons Attribution License 4.0 International License

\begin{abstract}
In this research, the study of the effectiveness of virtual conceptual change laboratory (VCCLab) on reconstruction high school students' conception about parallel electrical circuit concept has been done. Misconception about parallel electrical circuit concept which was addressed in this study is the addition of identical branches to a parallel circuit will change the amount of electric current flowing in each existing branch circuit because the potential difference and resistance value in these parallel branches do not change. The VCCLab used in this research was the five-stage of lab activities oriented towards conceptual change developed by researchers. To support VCCLab activities, student worksheets and the necessary laboratory equipment have been developed. A pre-experiment method with one group pretest-posttest design was used. The research subjects were 36 high school students consisting of 18 female students and 18 male students chosen by purposive sampling. Data were collected by conceptual test in the four-tier test format concerning parallel electrical circuit concept, which has previously been validated and tested for its reliability. The results of this study show that the number of male students,
\end{abstract}

whose misconceptions can be remediated is $83,3 \%$, while the number of female students, whose misconceptions $88,9 \%$. These results indicate that: first, the use of VCCLab has a high effectiveness in remediating high school students' misconceptions about the concept of parallel electrical circuit; second, there is no gender bias from the use of $V C C L a b$ in the process of remediating physics misconceptions.

Keywords Virtual Conceptual Change Lab, Misconception Remediation, Parallel Electrical Circuit Concept

\section{Introduction}

One Ownership of conceptions that are not in accordance with scientific conceptions among students is often found in physics courses at the high school level. The conception which is not in accordance with scientific conception is known as a misconception. Misconception 
hinders the assimilation of new knowledge in the minds of students. Misconceptions are difficult to cure because students are not aware of any misconceptions in their minds.

According to the literature, many things can be a source of causes for the emergence of misconceptions, including pre-conceptions, experiences in daily life, language, culture, teachers, textbooks, and learning [5]. One source of the causes of misconceptions among students is learning done by teachers in the classroom. The researchers found various misconceptions in physics because the learning process organized by the teacher did not support the process of constructing scientific conceptions in the minds of students. Misconceptions that occur because of inaccuracies in the learning process by teachers are called school-made misconceptions [3]. School-Made misconceptions can be identified after the physics learning process is carried out.

Misconceptions should not be allowed to remain in the minds of students, because of which students may become resistant to change with scientific ones, and students may reject accepting new ideas [9], thus they are obstacles for students in learning and understanding some concepts in science. In physics, one concept with another is usually interconnected.

For example, because in everyday life learners are of the view that the electric current flowing in a branch of a parallel electric circuit changes in value if the circuit is added or subtracted from the parallel electrical circuit with the same resistance value.

Whereas conceptually, the addition of identical branches in parallel circuits will not change the amount of electric current flowing in each branch of the existing circuit because of the potential difference and the resistance value at the parallel branches does not change [14].

The misconception is a situation that is difficult to be changed, because it is usually inherent in the minds of students and they are not aware that the conception they have is not in accordance with the scientific conception. Special approaches and strategies are needed to carry out misconception remediation that occurs in students. The approach that is often used is the conceptual change approach (CCA), while one of the strategies that are quite widely used is the cognitive conflict strategy. This approach and strategy were created based on constructivist theory. According to constructivist theory, students will construct conceptions related to a concept in two ways, namely the assimilation and the accommodation way [4]. Researchers who have used the CCA with cognitive conflict strategies in physics remedial teaching include: Baser [1], Kang et.al [11], and Madu \& Orji [13]. Teaching is specifically carried out with the aim of remediating the misconceptions that occur in students is known as remedial teaching.

Misconceptions must be remedied because misconceptions will identify where the student's mistakes are. Misconceptions are also resistant to the acceptance of new concepts, it is necessary to remediate misconceptions through remedial teaching activities. One of remedial teaching modes that can be used is a virtual laboratory mode and can be used for remediation of misconceptions virtual laboratories conception conversion (virtual conceptual change laboratory or VCCLab [14]. Virtual conceptual change laboratory (VCCLab) is a virtual laboratory activity type that is deliberately developed for remedial-oriented remedies of misconceptions experienced by learners. To carry out improvements through practicum activities in the laboratory, VCCLab model is needed, completing with syntax and supporting tools. VCCLab dikembangkan dengan mengacu pada pendekatan pengubahan konceptual (CCA). The strategy that is quite widely used is a cognitive conflict strategy. This approach and strategy were created based on constructivist theory. According to constructivist theory, students will construct conceptions related to a concept in two ways, namely the assimilation and the accommodation way [4]. In classical CCA, learning activities involve the teacher in making clear alternative conceptions in advance to design a learning approach that consists of knowledge that is contrary to previous knowledge of students and presents dissatisfaction in the minds of students [6]. Thus, students are not really active in constructing new scientific conceptions. Meanwhile, VCCLab activities facilitate students to actively remediate their misconceptions and build new scientific conceptions through practicum activities. This is because, in the VCCLab syntax, practicum activities are virtually the main activity carried out by students themselves to make them aware of the misconceptions they have so far, then remediate these misconceptions to scientific conceptions, where the scientific conceptions are found by students through practicum activities. According to Surtiana, the advantage of the mode of laboratory activities is that students can be facilitated to construct and change their conceptions through in-depth exploration activities by themselves. So the view of constructivism can be truly applied [23].

Simulation is a computerized version of the physical models that can be run over a period of time that has been set [1]. Physics teaching with use the media simulation can be used as an alternative of exploration activities using real lab [17]. With virtual laboratory, it is possible for students to directly manipulate the independent variables and can immediately see the effect of dependent variables in the virtual probe [20]. Results of other studies indicate that learning physics using simulations media makes physics content easier to be understood (e.g. Jaakko \& Nurmi [10]; Wibowo [24]; Samsudin et al [17] [18] [19]), and can provide constructive feedback to overcome students' misconception (e.g. Samsudin [17][18]; Wibowo et at [24]; Ronen \& Eliahu [16]). 
The purpose of this study is to test the effectiveness of the use of VCCLab model in facilitating the remediation misconceptions that occur in high school students related to the concept of Parallel Electrical Circuit which was addressed in this study is the addition of identical branches to a parallel circuit will change the amount of electric current flowing in each existing branch circuit because the potential difference and resistance value in these parallel branches does not change. Gender is one of the aspects reviewed in this research. This article reports the process and results obtained from the research activities that have been carried out.

\section{Materials and Methods}

The research method used in this study is the pre-experiment method. While the research adopts one-group pretest-posttest designs. The research subject was given two parallel conception tests during learning activities using VCCLab model as described in Table 1.

Table 1. Research design

\begin{tabular}{|c|c|c|c|}
\hline Subject & $\begin{array}{c}\text { Conception test } \\
1\end{array}$ & $\begin{array}{c}\text { Practicum } \\
\text { activities }\end{array}$ & $\begin{array}{c}\text { Conception } \\
\text { test } 2\end{array}$ \\
\hline $\mathrm{E}$ & $\mathrm{O}$ & $\mathrm{X}$ & $\mathrm{O}$ \\
\hline
\end{tabular}

Table 1 shows the research design used, in which $\mathrm{E}$ is an experimental group, $\mathrm{O}$ is a conception test related to the concept of a parallel electrical circuit, and $\mathrm{X}$ is the practicum activities which are oriented to the confrontation of conception, towards new scientific conception, and to strengthen and enrich new conception. In general, the VCCLab model used in this research consists of five-stage of lab activities oriented towards conceptual change, as shown in Figure 1.

\begin{tabular}{|c|c|c|}
\hline CCLab Stage Model & Students Activities & Support Devices \\
\hline $\begin{array}{l}\text { Identification of Students } \\
\text { 'Conception and Confidence } \\
\text { Level of Students' } \\
\text { Conception }\end{array}$ & $\begin{array}{l}\text { Students answer the conception test given at } \\
\text { the beginning of the LKPD }\end{array}$ & $\begin{array}{l}\text { The conception test is in the Four } \\
\text { Tier Test format related to the } \\
\text { Physics Concept being reviewed }\end{array}$ \\
\hline $\begin{array}{l}\text { Practicum activities oriented } \\
\text { to the confrontation of } \\
\text { conception beliefs }\end{array}$ & $\begin{array}{l}\text { Students carry out practicum activities to } \\
\text { confront the conceptual beliefs they have }\end{array}$ & $\begin{array}{l}\text { Practical worksheets for the } \\
\text { confrontation of conception } \\
\text { beliefs in verification lab designs } \\
\text { Real or virtual practicum } \\
\text { equipment }\end{array}$ \\
\hline $\begin{array}{lcr}\begin{array}{l}\text { Practical } \\
\text { oriented } \\
\text { scientific conceptions }\end{array} & \text { towards } \\
\text { sciew }\end{array}$ & $\begin{array}{l}\text { Students carry out practical activities } \\
\text { oriented to the discovery of new scientific } \\
\text { conceptions to replace old wrong } \\
\text { conceptions by using discovery lab designs }\end{array}$ & $\begin{array}{l}\text { LKPD discovery lab } \\
\text { Real or virtual practicum } \\
\text { equipment. }\end{array}$ \\
\hline $\begin{array}{l}\text { Practical activities to } \\
\text { strengthen and enrich new } \\
\text { conceptions }\end{array}$ & $\begin{array}{l}\text { Students carry out practicum activities to } \\
\text { strengthen and enrich new scientific } \\
\text { conceptions }\end{array}$ & $\begin{array}{l}\text { Practical worksheets for the } \\
\text { confrontation of conception } \\
\text { beliefs in verification lab designs } \\
\begin{array}{l}\text { Real or virtual practicum } \\
\text { equipment }\end{array}\end{array}$ \\
\hline $\begin{array}{l}\text { Final Conception } \\
\text { Identification and Conceptual } \\
\text { Confidence Level }\end{array}$ & $\begin{array}{l}\text { Students answer the conception test that is } \\
\text { given at the end of the LKPD }\end{array}$ & $\begin{array}{l}\text { The conception test is in the Four } \\
\text { Tier Test format related to the } \\
\text { Physics Concept being reviewed }\end{array}$ \\
\hline
\end{tabular}

Figure 1. Stages, Activities, Material of VCCLab model 
The research subjects were 36 high school students consisting of 18 female and 18 male students in one of the high schools in the West Bandung district of West Java province and were chosen by purposive sampling. Lab activities are carried out cooperatively in small groups. One of the weaknesses of classic CCA is that it only focuses on cognitive factors while ignoring non-cognitive factors such as affective and motivational [6] [11] [20]. However, the remediation activity of misconceptions through the VCCLab model was carried out in groups. Thus, affective and psychomotor aspects, such as curiosity, cooperation, ability to collaborate will also be formed.

Data were collected by two parallel conception tests in the four-tier test format concerning Parallel Electrical Circuit concept (PECCFTTest), which has previously been validated and tested for its reliability. Based on the results of expert judgment, the instruments used in this study have construct and content validity in a very good category. While based on the results of the reliability analysis using the test-retest method, the instrument has reliability coefficient of 0.76 which indicates that the conception test instrument used in this study has a high reliability. Figure 2 shows a sample of PECCFTTest items used in this study.

Table 2 shows the guidelines used to determine the state of student conceptions based on conception test data in the Four Tier test format [7]. The quantity of students who achieved conception reconstruction after participating in VCCLab activities was analyzed using techniques similar to those used by Surtiana et al [22][23] [24].

Table 2. Students' conception categories based on conception test results data

\begin{tabular}{|c|c|c|c|c|}
\hline Tier 1 & Tier 2 & Tier 3 & Tier 4 & Conception Category \\
\hline $\begin{array}{l}\text { True } \\
(\mathrm{T})\end{array}$ & Sure (S) & $\begin{array}{l}\text { True } \\
(\mathrm{T})\end{array}$ & Sure $(\mathrm{T})$ & Scientific Conception (SC) \\
\hline $\begin{array}{l}\text { True } \\
(\mathrm{T})\end{array}$ & Sure (S) & $\begin{array}{l}\text { True } \\
(\mathrm{T})\end{array}$ & $\begin{array}{c}\text { Not Sure } \\
\text { (NS) }\end{array}$ & No Conception (NC) \\
\hline $\begin{array}{l}\text { True } \\
\text { (T) }\end{array}$ & $\begin{array}{l}\text { Not Sure } \\
\text { (NS) }\end{array}$ & $\begin{array}{l}\text { True } \\
\text { (T) }\end{array}$ & Sure (S) & No Conception (NC) \\
\hline $\begin{array}{l}\text { True } \\
(\mathrm{T})\end{array}$ & $\begin{array}{c}\text { Not Sure } \\
\text { (NS) }\end{array}$ & $\begin{array}{l}\text { True } \\
(\mathrm{T})\end{array}$ & $\begin{array}{c}\text { Not Sure } \\
\text { (NS) }\end{array}$ & No Conception (NC) \\
\hline $\begin{array}{l}\text { True } \\
\text { (T) }\end{array}$ & Sure (S) & $\begin{array}{l}\text { False } \\
(\mathrm{F})\end{array}$ & Sure (S) & No Conception (NC) \\
\hline $\begin{array}{l}\text { True } \\
(\mathrm{T})\end{array}$ & Sure (S) & $\begin{array}{c}\text { False } \\
(\mathrm{F})\end{array}$ & $\begin{array}{c}\text { Not Sure } \\
\text { (NS) }\end{array}$ & No Conception (NC) \\
\hline $\begin{array}{l}\text { True } \\
(\mathrm{T})\end{array}$ & $\begin{array}{l}\text { Not Sure } \\
\text { (NS) }\end{array}$ & $\begin{array}{l}\text { False } \\
\text { (F) }\end{array}$ & Sure (S) & No Conception (NC) \\
\hline $\begin{array}{l}\text { True } \\
(\mathrm{T})\end{array}$ & $\begin{array}{c}\text { Not Sure } \\
\text { (NS) }\end{array}$ & $\begin{array}{l}\text { False } \\
(\mathrm{F})\end{array}$ & $\begin{array}{c}\text { Not Sure } \\
\text { (NS) }\end{array}$ & No Conception (NC) \\
\hline $\begin{array}{c}\text { False } \\
(\mathrm{F})\end{array}$ & Sure (S) & $\begin{array}{l}\text { True } \\
(\mathrm{T})\end{array}$ & Sure (S) & No Conception (NC) \\
\hline $\begin{array}{c}\text { False } \\
(\mathrm{F})\end{array}$ & Sure (S) & $\begin{array}{l}\text { True } \\
(\mathrm{T})\end{array}$ & $\begin{array}{c}\text { Not Sure } \\
\text { (NS) }\end{array}$ & No Conception (NC) \\
\hline $\begin{array}{c}\text { False } \\
(\mathrm{F})\end{array}$ & $\begin{array}{c}\text { Not Sure } \\
\text { (NS) }\end{array}$ & $\begin{array}{l}\text { True } \\
(\mathrm{T})\end{array}$ & Sure (S) & No Conception (NC) \\
\hline $\begin{array}{l}\text { False } \\
(\mathrm{F})\end{array}$ & $\begin{array}{c}\text { Not Sure } \\
\text { (NS) }\end{array}$ & $\begin{array}{l}\text { True } \\
\text { (T) }\end{array}$ & $\begin{array}{c}\text { Not Sure } \\
\text { (NS) }\end{array}$ & No Conception (NC) \\
\hline $\begin{array}{l}\text { False } \\
(\mathrm{F})\end{array}$ & Sure (S) & $\begin{array}{l}\text { False } \\
(\mathrm{F})\end{array}$ & Sure (S) & No Conception (NC) \\
\hline $\begin{array}{l}\text { False } \\
(\mathrm{F})\end{array}$ & Sure (S) & $\begin{array}{l}\text { False } \\
(\mathrm{F})\end{array}$ & $\begin{array}{l}\text { Not Sure } \\
\text { (NS) }\end{array}$ & No Conception (NC) \\
\hline $\begin{array}{c}\text { False } \\
(\mathrm{F})\end{array}$ & $\begin{array}{c}\text { Not Sure } \\
(\mathrm{NS})\end{array}$ & $\begin{array}{c}\text { False } \\
(\mathrm{F})\end{array}$ & Sure (S) & No Conception (NC) \\
\hline $\begin{array}{c}\text { False } \\
(\mathrm{F})\end{array}$ & $\begin{array}{c}\text { Not Sure } \\
(\mathrm{NS})\end{array}$ & $\begin{array}{c}\text { False } \\
(\mathrm{F})\end{array}$ & $\begin{array}{c}\text { Not Sure } \\
\text { (NS) }\end{array}$ & No Conception (NC) \\
\hline
\end{tabular}


Tier 1

The image below shows four identical lamps A, B, C, and D installed in parallel with each other except for lamp D because switch S is still open. Lamps A, B and C are equally bright, while lamp D is still off. If then switch $\mathrm{S}$ in the circuit is closed so that the circuit now has four branches (lamp D is on), how do the lights A, B and C turn on now compared to when switch S is still open (lamp D goes out)?

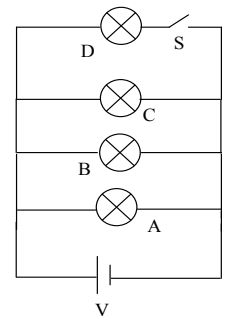

A. The Lights A, B, C are now as bright as they were before connecting lamp D.

B. The lights A, B, C are now brighter than they were before the D lamps were connected.

C. The lights A, B, C are now dimmer than they were before the D lamps were connected

Tier 2

Are you sure about the answer you gave in Tier 1 ?

A. Sure

B. Not Sure

Tier 3

The right explanation according to your choice in Tier 1 is

A. A parallel circuit is a circuit that divides the electric current, so that when the circuit is added one more parallel branch, the electric current flowing in the four branches will be smaller because the total current is divided by more branches.

B. The addition of identical branches to a parallel circuit will not change the amount of electric current flowing in each existing branch circuit because the potential difference and resistance value in these parallel branches do not change.

C. The more lights are paralleled, the smaller the total resistance will be so that the electric current flowing in each branch of the parallel circuit will be greater than before.

D. The more lights are parallelized, the greater the total resistance will be so that the electric current flowing in each branch of the parallel circuit will be smaller than before.

Tier 4

Are you sure about the answer you gave in Tier 3 ?

A. Sure

B. Not Sure

Figure 2. Sample of PECCFTTest items used in this study about Parallel Electrical circuit Using Virtual Conceptual Change Laboratory (VCCLab) Activity

The quantity decrease of students who have misconceptions $(\Delta M)$ on parallel electrical circuit concept is determined by a formula (1) which is an adaptation of the N-gain definition developed by Hake [8]:

$$
\Delta M=\frac{M_{\text {pre }}-M_{\text {post }}}{M_{\text {pre }}-M_{\text {ideal }}}
$$

with $\Delta M$ decrease criteria as shown in Table 3.

Table 3. The criteria of quantity decrease of students who have misconception

\begin{tabular}{|c|c|}
\hline$\Delta M$ Range & Decrease Category \\
\hline$\Delta M<0.3$ & Low \\
\hline $0.3 \leq \Delta M<0.7$ & Medium \\
\hline $0.7 \leq \Delta M<1.0$ & High \\
\hline
\end{tabular}

The simulation software used in this study to conduct virtual laboratory is Circuit Construction Kit (CCK). CCK is developed by the Physics Education Technology (PheT) project at the University of Colorado, United States (http://phet.colorado.edu/web-pages/index.html). By using $\mathrm{CCK}$, students can perform virtual experiments similar to the real experiment [23].

Conceptual change method by using cognitive conflict strategy used in this study is a process disclosed [16]; it starts with the disclosure process of the current concepts owned by the students. The next step is confrontation activities of the conception believed by students to create a cognitive conflict situation in their minds. After that, the reconstruction of the former conception with the new conception through scientific explanation and the final stage is the strengthening and expansion process of concepts. At the scientific explanation process, interactive demonstration method is used; it is based on the consideration that this method allows the concept construction to be discovered by the students through the demonstrations presented by lecturer. Zimrot and Ashkenazi [25] states that interactive demonstration is a student-centre learning method, so that students can construct their own new conception to replace the former erroneous conception through demonstration of physical phenomena that are presented and discussed in an interactive teaching. 
Another goal of this research is to find out about the effect of gender on the achievement of conception reconstruction in the implementation of the VCCLab model on the parallel electrical circuit concept. The research hypothesis proposed is "HA: There are differences in the number of male and female students who reach the conception reconstruction related to the parallel electrical circuit as the effect of applying the VCCLab model.

\section{Result and Discussion}

By using the categorization guidelines for students' conceptions as shown in Table 3, it can be determined what state of conceptions students have before and after participating in VCCLab activities.

Having known the condition of the students' conceptions before and after the VCCLab model, a pattern of the conceptual change that occurred from before to after the VCCLab model can be obtained. With the pattern of conceptual changes achieved by students, the effectiveness of implementation of VCCLab model remediating the misconceptions of high school students can be determined. Figure 3 shows the pattern of conceptual change of female (F) and male (M) students in Misconception before and after participating in VCCLab model.

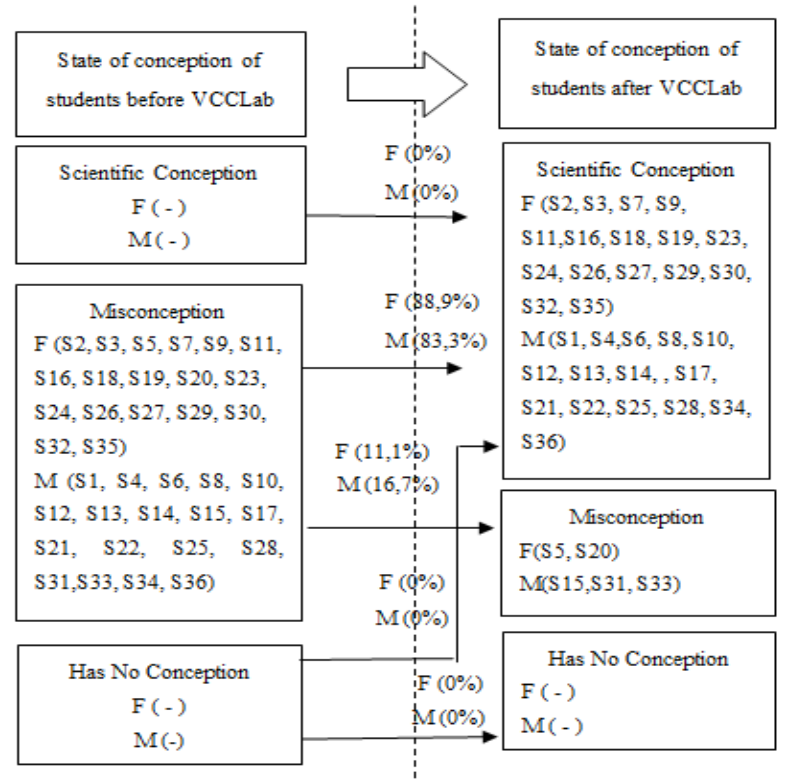

Figure 3. Pattern of conceptual change of female and male students in misconception before and after $\mathrm{VCClab}$
In Figure 3 it appears that $88,9 \%$ of female students and $83,3 \%$ of male students change their conception from a mistaken one to a scientific one. These changes show that VCCLab model can facilitate the revision or reconstruction of students' conceptions from erroneous conceptions to scientific concepts related to misconception.

Figure 4 shows a bar chart of the number of female and male students who have misconceptions related to misconception before and after VCCLab model. In the figure, it appears that there was a significant decrease in the number of female and male students who have misconceptions from before to after VCCLab model.

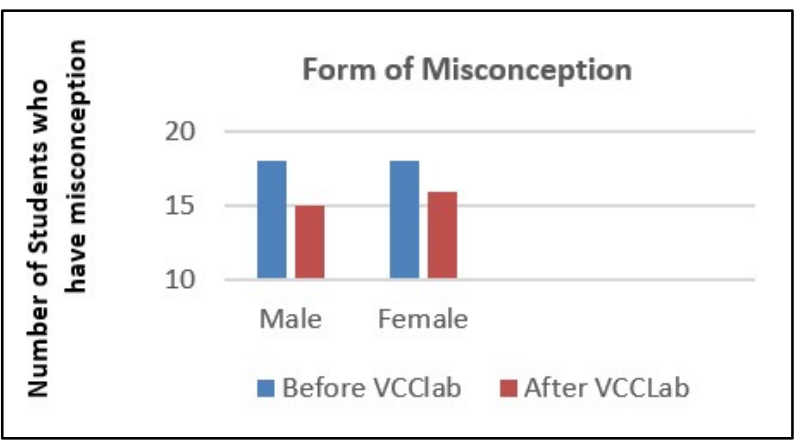

Figure 4. Bar chart of the number of female and male students in misconception before and after VCCLab activities

Table 3 shows the quantity of female and male students whose misconceptions were remediated during implementation of $V C C L a b$ model related to the concept of parallel electrical circuit.

In Table 3, it appears that before VCCLab model, the number of female and male students who had misconceptions related is 18 each, and after VCCLab model the number has drastically decreased to only 2 for female students and 3 for male students. Based on data of the quantity of students whose misconceptions before and after VCCLab model, a decrease can be calculated in the quantity of students whose misconceptions are related to the concept of parallel electrical circuit. The results show that: related to misconceptions the quantity of misconceptions of male students decreased by 0.83 and for female students the quantity decreased by 0.89 . These results indicate that the implementation of the VCCLab model has a high effectiveness in remediating the misconceptions that occur among high school students regarding the concept of parallel electrical circuit.

Table 3. Quantity of female and male students who are misconceptions on the concept of Parallel Electrical Circuit was remediated

\begin{tabular}{|c|c|c|c|c|c|c|c|c|}
\hline \multirow{2}{*}{ Misconception } & \multicolumn{2}{|c|}{$\begin{array}{c}\text { Number of students whose } \\
\text { misconceptions } \\
\text { before VCCLab }\end{array}$} & \multicolumn{2}{|c|}{$\begin{array}{c}\text { Number of students whose } \\
\text { misconceptions } \\
\text { after VCCLab }\end{array}$} & \multicolumn{2}{|c|}{$\begin{array}{c}\text { Decreasing the number of } \\
\text { students who are } \\
\text { misconceptions }\end{array}$} & \multicolumn{2}{c|}{ Category of reduction } \\
\hline & $\mathrm{F}$ & $\mathrm{M}$ & $\mathrm{F}$ & $\mathrm{M}$ & $\mathrm{F}$ & $\mathrm{M}$ & $\mathrm{F}$ & $\mathrm{M}$ \\
\hline $\mathrm{MC}$ & 18 & 18 & 2 & 3 & 0,89 & 0,83 & High & High \\
\hline
\end{tabular}


When we compare of male students to female students whose misconceptions related can be remediated, the numbers are almost balanced. This indicates that there is no gender bias in the process of remediating misconceptions through VCCLab model. This fact is supported by the results of different test numbers of male and female students who achieve remediation of misconceptions using the Mann-Whitney test at the level of confidence $(\alpha=0.05)$ as shown in Table 4 .

Table 4. Test the different numbers of male and female students who have achieved conception reconstruction

\begin{tabular}{|c|c|c|c|}
\hline Misconception & Mann-Whitney U & $\begin{array}{c}\text { Asymp. } \\
\text { Sig. }\end{array}$ & Conclusion \\
\hline MC & 0.760 & 0.08 & $\begin{array}{c}\text { Not significantly } \\
\text { different }\end{array}$ \\
\hline
\end{tabular}

In Table 4 it appears that for misconception that occurred in the parallel electrical circuit, the obtained value of Asymp. Sig. is greater than the level of confidence $(\alpha=0.05)$. This shows that the proposed hypothesis is rejected, which means that for the misconception, there is no difference in the number of male and female students who achieve remediation of the misconception. Statistical test results show that the $V C C L a b$ model is suitable for remedial teaching activities for both male and female students. The success of the VCCLab model in remediating these misconceptions is inseparable from the effectiveness of cognitive conflicts that are presented in the VCCLab model. These results are in line with Baser research which states that the use of cognitive conflict has significantly reduced the number of students who have misconceptions [1]. In addition, the results show that cognitive conflict does not significantly influence the differences in achievement achieved by male and female students. The use of CCA in the VCCLab model also shows the effectiveness of VCCLab in the remediation of misconceptions, as according to many researches [1] [2] [11] [12]. The presence of computer simulations in the VCCLab model supports the decrease in the number of students who experience misconceptions. These results are in line with Wibowo [24] who stated that the use of virtual simulations in computer format can effectively reduce the number of students who have misconceptions.

The following is an example of student responses to the questions in concept identification before VCCLab activites, Tier 1 : The image below shows four identical lamps A, B, C, and D installed in parallel with each other except for lamp D because switch S is still open. Lamps A, $\mathrm{B}$ and $\mathrm{C}$ are equally bright, while lamp $\mathrm{D}$ is still off. If then switch $\mathrm{S}$ in the circuit is closed so that the circuit now has four branches (lamp D is on), how is the state of lights A, B and C currently on compared to when switch $\mathrm{S}$ is still open (lamp D is off)?

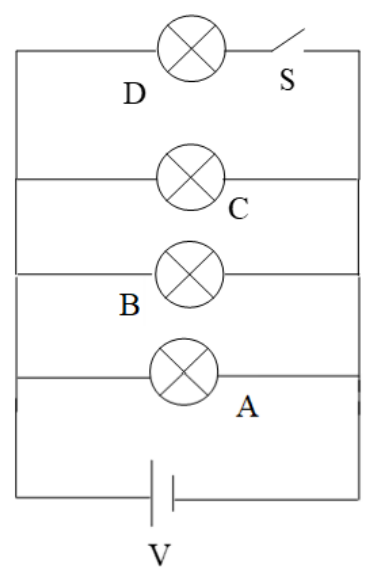

They answer : C. The lights A, B, C are now dimmer than they were before the $\mathrm{D}$ lamps were connected

Tier 2 : Sure

Tier 3 : The exact explanation for your answer choice on Tier 1 is (A). A parallel circuit is a circuit for dividing the electric current, so that when the circuit is added one more parallel branch, the electric current flowing in the four branches will be smaller because the total current is divided by more branches.

Tier 4 : Sure

The answer was incorrect so that was misconception about parallel electrical circuit. Misconception about parallel electrical circuit concept which was addressed in this study is the addition of identical branches to a parallel circuit will change the amount of electric current flowing in each existing branch circuit because the potential difference and resistance value in these parallel branches do not change.

After the student have $V C C L a b$ were the five-stage of lab activities : 1) Identification of Students 'Conception and Confidence Level of Students' Conception, 2) Practicum activities oriented to the confrontation of conception beliefs, 3) Practical activities are oriented towards new scientific conceptions, 4) Practical activities to strengthen and enrich new conceptions, 5) Final Conception Identification and Conceptual Confidence Level [20] [21]..

The answer of Tier 1 : A. The lights A, B, C are now bright with the time before lamp D was applied.

Tier 2 : sure

Tier 3 : B. The addition of identical branches to a parallel circuit will not change the amount of electric current flowing in each existing branch because the potential difference and resistance value in the parallel branches do not change.

Tier 4 : Sure

This means that the conceptions that students have regarding parallel electrical circuit have changed, which means that students already have the correct concept. It 
can be concluded that the implementation of the VCCLab model in remedial teaching about parallel electrical circuit concept has a high effectiveness on reconstruction high school students' conception.

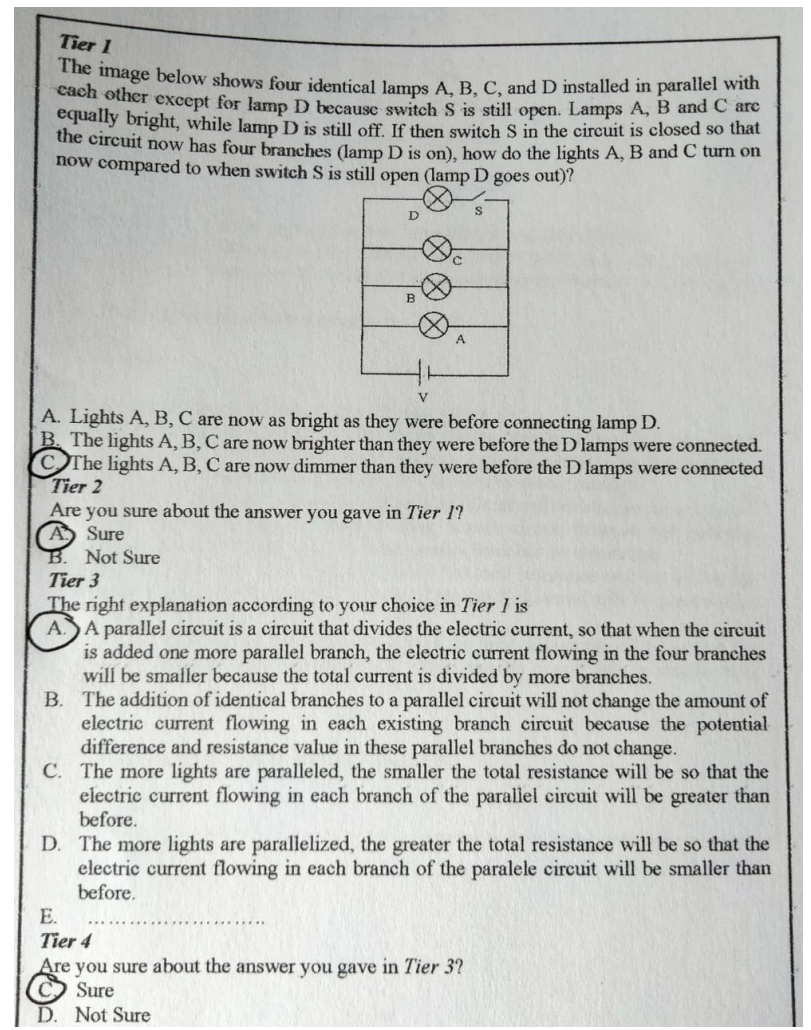

Figure 5. The results of student work question before $V C C L a b$ activities

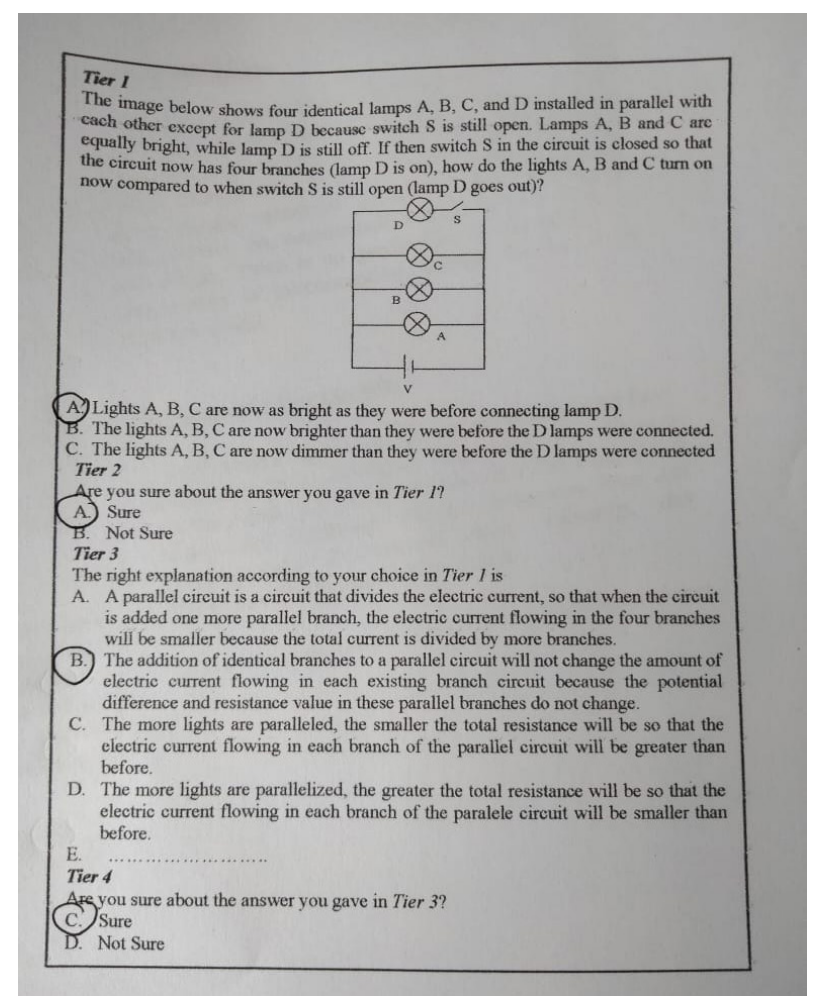

Figure 6. The results of student work question after VCCLab activities

\section{Conclusions}

Based on research data on the implementation of the VCCLab model in remedial teaching related to the concept of parallel electrical circuits, it can be concluded that the implementation of the VCCLab model in remedial teaching about parallel electrical circuit concept has a high effectiveness on reconstruction high school students' conception. There is no gender bias in the process of remediation of misconceptions through the use of the VCCLab model. This shows that VCCLab plays an important role in facilitating the reconstruction of students' conceptions on the concept of parallel electrical circuits. Unlike the CCA which has been used by other researchers to reconstruct the conceptions of students, through VCCLab students can directly find scientific conceptions through practicum activities, so that learning activities will be more meaningful. Therefore, VCCLab activity can be effectively used in remediation activities for misconceptions related to the parallel electrical circuit concept. However, the next research is needed, such as relate some parts of the VCCLab syntax, so that they have the potential to be better, for example by adding an activity to create a new prototype that can be used in practicum activities on the same concept.

\section{Acknowledgments}

Our deepest thanks to the various parties who have supported this research, especially to Sekolah Pascasarjana UPI and Direktorat Riset dan Pengabdian Masyarakat, Direktorat Jenderal Penguatan Riset dan Pengembangan Kementerian Riset, Teknologi, dan Pendidikan Tinggi Republik Indonesia.

\section{REFERENCES}

[1] Baser, M, "Effects of conceptual change and traditional confirmatory simulations on pre-service teachers' understanding of direct current circuits,"Journal of Science Education and Technology, Vol.15, pp 367-381, 2006. DOI:10.1007/s10956-006-9025-3.

[2] Basori, H., Suhandi, A., Kaniawati, I., \& Rusdiana, D, "Concept progression of high school students related to the concept of parallel electric circuits as the effect of applying CCROI integrated with T-ZPD strategy," Journal of Physics: Conference Series, DOI: 10.1088/1742-6596/1521/2/02200 9

[3] Barke, H. D., dkk. Misconceptions in Chemistry, Springer, Berlin, 2009. DOI:10.1007/978-3-540-70989-3.

[4] Cakir, M, "Constructivist Approaches to Learning in Science and Their Implications for Science Pedagogy: A Literature Review," International Journal of Environmental \& Science Education,Vol.3(4), pp 193-206, 2008. 
ijese.2008.009.

[5] Cetin, G., Ertepinar, H., Geban, O, "Effect of conceptual change textbased instruction on ecology, attitudes toward biology and environment," Educational Research Educations, Vol. 10(3), pp 259-273, 2015. DOI: 10.5897/ERR2014.2038

[6] Duit, R., \& Treagust, D., F, "Conceptual change: A powerful framework for impriving science teaching and learning," International Journal of Science Education, Vol. 25 (6), pp 671-688, 2003. DOI: 10.1080/0950069032000076652

[7] Gurel, D. K., Eryılmaz, A., McDermott, L. C," A Review and Comparison of Diagnostic Instruments to Identify Students' Misconceptions in Science," Eurasia Journal of Mathematics, Science \& Technology Education, Vol.11(5), pp 989-1008.2015.

[8] Hake, R, R, "Interactive-engagement versus traditional methods: A six-thousand-student survey of mechanics test data for introductory physics courses," American Journal of Physics, Vol 66(1), pp 64-74.1998. DOI: 10.1119/1.18809.

[9] Hynd, C. R., McNish, M. M., Qian, G., Keith, M., Lay, K, "Learning counterintuitive physics concept: the effect of text and educational environment," Retrieved from curry.virginia.edu/go/clic/nrrc/phys_r16.html.2015.

[10] Jaakkola, T., \&Nurmi, S, "Fostering elementary school students' understanding of simple electricity by combining simulation and laboratory activities," Journal of Computer Assisted Learning, Vol 24 (4), pp 271-283.2008.DOI:10.11 11.

[11] Kang, H., Scharmann, L. C., Kang, S., Noh, T,"Cognitive conflict and situational interest as factors influencing conceptual change," International Journal of Environmental \& Science Education, Vol. 5, No. 4, pp.383-405.2010.

[12] Madu, B. C., and Orji, E, "Effects of Cognitive Conflict Instructional Strategy on Students' Conceptual Change in Temperature and Heat, "SAGE Open July-September 2015: 1-9.2015. DOI: 10.1177/2158244015594662.

[13] Putri, K. L., Suhandi, A., Surtiana, Y," The Development of Virtual Conceptual Change Laboratory (VCCLab) for Conception Reconstruction through Lab Virtual Activity," Article International Conference on Mathematics and Science Education (ICMScE), Bandung, UPI.2020.

[14] Perkins, K., Adams, W., Dubson, M., Finkelstein, N., Reid, S., Wieman, C., \& LeMaster, R, PhET: Interactive Simulations for Teaching and Learning Physics. The Physics Teacher, 44(1), 18-23.2006.

[15] Posner, G.J., Strike, K.A., Hewson, P.W. and Gertzog, W.A. Accommodation of a scientific conception: toward a theory of conceptual change. Science Education, 66, 211-227.1982. DOI:10.1002/sce.3730660207.
[16] Ronen, M., Eliahu, M, "Simulation - A bridge between theory and reality: The case of electric circuits," Journal of Computer Assisted Learning, Vol.16 (1), pp 14-26, 2000. DOI:10.1046.

[17] Samsudin, A., Suhandi, A., Rusdiana, D., Kaniawati, I., \&Coștu, B, "Investigating the effectiveness of an active learning based-interactive conceptual instruction (ALBICI) on electric field concept," Asia-Pacific Forum on Science Learning and Teaching, Vol.17 (1), pp 1-41. 2016.

[18] Samsudin, A., Suhandi, A., Rusdiana, D., Kaniawati, I., \& Coştu, B, "Conceptual Understanding on Magnetic Field Concept through Interactive Conceptual Instruction (ICI) with PDEODE*E Tasks," Advanced Science Letters, Vol 23 (2), pp 1205-1209. 2016

[19] Samsudin, A., Suhandi, A., Rusdiana, D., \& Kaniawati, I, "Preliminary Design of ICI-based Multimedia for Reconceptualizing Electric Conceptions at Universitas Pendidikan Indonesia," Journal of Physics Conference Series, 739 (1),012006.2016.

[20] Sinatra, G., "The "warning trend" in conceptual change research: The legacy of Paul R. Pintrich," Educational Psychologist, Vol 40 (2), pp 107-115

[21] Suhandi, A., Samsudin, A., Suhendi, E., Hermita, N.,Nur Syamsiah, E., Costu, B, "Facilitating Conceptual Changes of High School Students regarding Concepts in Static Electricity and DC Circuits through the Use of VMSCDCCText,"Universal Journal of Educational Research, Vol.8(3), pp 815-822, 2020. DOI: 10.13189/ujer.2020.080312.

[22] Suhandi, A., Surtiana, Y., Samsudin, A., Siahaan, P., Setiawan, W, "Fostering High School Students' Misconception about Boiling Concept Using Conceptual Change Laboratory (CCLab) Activity.," Universal Journal of Educational Research. Vol 8(6), pp 2211-2217.2020. DOI: 10.13189/ujer.2020.080603.

[23] Surtiana, Y., Suhandi, A., Samsudin, A., Siahaan, P., Setiawan, W, "The preliminary study of the application of the conceptual change laboratory (CC-Lab) for overcoming high school students misconception related to the concept of floating, drifting and sinking," Journal of Physics Conference Series 1521(1):022018. DOI: 10.1088.2020

[24] Wibowo, F.C., Suhandi, A., Rusdiana, D., Ruhiat, Y., Darman, D.R., Samsudin, A, "Effectiveness of Microscopic Virtual Simulation (MVS) for Conceptualizing Students' Conceptions on Phase Transitions," Advanced Science Letters, Vol.23 (2), pp 839-843.2017.

[25] Zimrot, R., Ashkenazi, "Interactive lecture demonstrations: a tool for exploring and enhancing conceptual change," Chemistry Education Research and Practice, Vol. 8(2), pp 197-211, 2007. 